\title{
PERDAGANGAN PEREMPUAN DAN ANAK SEBAGAI KEJAHATAN TRANSNASIONAL
}

\author{
Yudhya Prasetia
}

Universitas Muhammadiyah Yogyakarta

Email: yudhaprrasetya12@gmail.com

\begin{abstract}
Organized crime in the transnational trafficking of women and children is a serious and farreaching crime and can even be classified as crimes against humanity as stated in the Rome Statute (1998) which regulates the permanent international criminal court. The objective of the provisions in protocol II is the criminal organization behind the trafficking of women and children, namely by punishing the perpetrators and protecting their victims, namely women and children. In the Palermo Convention2000) it is emphasized that the main objective is to enhance and strengthen cooperation between states parties in preventing and eradicating the five types of crimes which are the jurisdiction of the convention. This paper is the result of a research useing normative juridical approach by reviewing, and examining secondary data in the form of legislation, legal principles, and cases relating to the problem regarding to the trafficking of women and children.
\end{abstract}

\section{Keywords: Transnasional Crime, State jurisdiction, Trafficking of children and women}

\section{PENDAHULUAN}

Transnasional Crime memiliki beberapa definisi, hal ini terkait dengan latar belakang pendidikan, pengalaman, serta kepentingan yang menyebabkan beberapa Ahli merumuskan definisi Transnasional Crime serta Radikalisme sangat bervariasi, namun secara garis besar terdapat kata kunci yang dapat digunakan sebagai panduan dalam merumuskan pengertian Transnational Crime adalah (1) Suatu perbuatan sebagai suatu kejahatan dan (2) Terjadi antar negara atau Lintas negara. Dari kedua kata kunci tersebut dapat dijelaskan bahwa transnational crime merupakan suatu kejahatan yang terjadi lintas negara, dalam pengertian bahwa suatu perbuatan tersebut dapat dikategorikan sebagai kejahatan apabila terdapat hukum yang dilanggar. Sehingga bisa saja terjadi suatu perbuatan yang dirumuskan, dirancang, disiapkan, dilaksanakan dalam suatu negara bukan merupakan kejahatan, namun ketika hasil kejahatan yang diatur, disiapkan lintas batas negara untuk masuk ke yurisdiksi negara yang berbeda lantas dikategorikan sebagai kejahatan transnasional crime. 


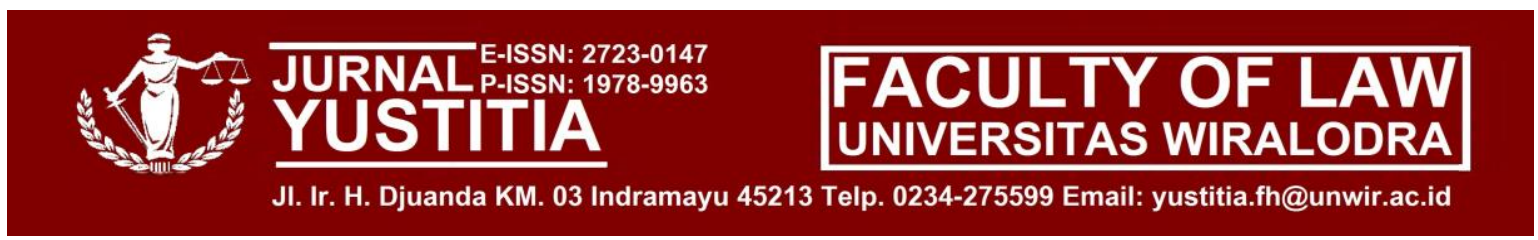

Semakin maraknya masalah perdagangan orang di berbagai negara, terutama di negara berkembang termasuk Indonesia, telah menjadi perhatian masyarakat internasional. Perserikatan Bangsa-Bangsa (PBB) telah berhasil mengadakan perjanjian internasional berjudul "Protocol to prevent, suppress and punish trafficking in person, especially women and children, sumpplementing the United Nation Convention against Trannational Organized Crime" (Protokol PBB untuk mencegah, menekan dan menghukum pelaku perdagangan perempuan dan anak). Kata "traficking" yang masuk ke dalam judul perjanjian internasional tersebut, berasal dari kata Trafic yang artinya perdagangan. Pedanan kata orang yang berdagang/berjualan yakni "Trafficker" yang artinya pedagang. Persatuan Bangsa-bangsa (PBB) mendefinisikan human trafficking atau perdagangan manusia sebagai perekrutan, pengiriman, pemindahan, penampungan, atau penerimaan seseorang, dengan ancaman, atau penggunaan kekerasan, atau bentukbentuk pemaksaan lain, penculikan, penipuan, kecurangan, penyalahgunaan kekuasaan atau posisi rentan, memberi atau menerima bayaran atau manfaat untuk memperoleh ijin dari orang yang mempunyai wewenang atas orang lain untuk tujuan eksploitasi.

Sedangkan menurut UU No. 21 tahun 2007 tentang Pemberantasan Tindak Pidana Perdagangan Orang (PTPPO) definisi perdagangan orang adalah tindakan perekrutan, pengangkutan, penampungan, pengiriman, pemindahan, atau penerimaan seseorang dengan ancaman kekerasan, penggunaan kekerasan, penculikan, penyekapan, pemalsuan, penipuan, penyalahgunaan kekuasaan atau posisi rentan, penjeratan utang atau memberi bayaran atau manfaat, sehingga memperoleh persetujuan dari orang yang memegang kendali atas orang lain tersebut, baik yang dilakukan di dalam negara maupun antar negara, untuk tujuan eksploitasi atau mengakibatkan orang tereksploitasi ${ }^{1}$.

Pelaku dalam perdagangan anak dan perempuan dapat dibedakan dalam tiga unsur. Pembedaan dilakukan berdasarkan peranannya masing-masing dalam tindakan perdagangan:

1. Pihak yang berperan pada awal perdagangan;

2. Pihak yang menyediakan atau menjual orang yang diperdagangkan;

3. Pihak yang berperan pada akhir rantai perdagangan sebagai penerima/pembeli orang yang diperdagangkan atau sebagai pihak yang menahan korban untuk dipekerjakan secara paksa dan yang mendapatkan keuntungan dari kerja itu.

\footnotetext{
${ }^{1}$ Abang Ishar, "Perdagangan Perempuan”, Jurnal Final Rahema, Vol. 2, No.1, Juni 2017.
} 


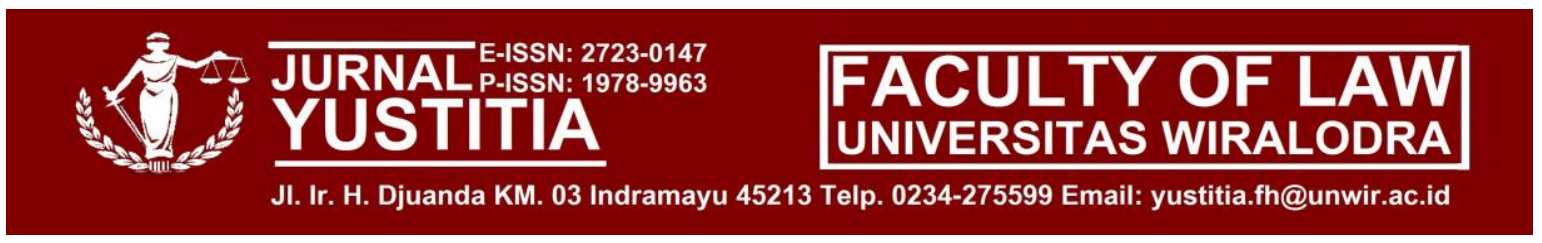

Modus operandi rekrutmen terhadap kelompok rentan biasanya dengan rayuan, menjanjikan berbagai kesenangan dan kemewahan, menipu atau janji palsu, menjebak, mengancam, menyalahgunakan wewenang, menjerat dengan hutang, mengawini atau memacari, menculik, menyekap atau memerkosa. Modus lain berkedok mencari tenaga kerja untuk bisnis hiburan, kerja di perkebunan atau bidang jasa di luar negeri dengan upah besar.

Berdasarkan uraian dalam pendahuluan di atas maka penulis akan membahas mengenai penyelesaian permasalahan perdagangan manusia sebagai salah satu kejahatan transnasional dan penerapan yurisdiksi negara dalam penyelesaian perkara kejahatan korupsi transnasional ${ }^{2}$.

\section{IDENTIFIKASI MASALAH}

Berdasarkan uraian diatas yang telah diuraikan diatas, maka permasalahan yang hendak dikemukakan dalam penulisan ini adalah sebagai berikut:

1. Bagaimanakah Proses Terjadinya Kasus Tindak Pidana Perdagangan Perempuan dan Anak?

2. Apa saja Faktor Penyebab Terjadinya Perdagangan Perempuan dan Anak?

\section{METODE}

Sifat penelitian dalam artikel ini adalah deskriptif, dan dilakukan melalui metode peradilan standar. Jenis dan sumber data yang digunakan adalah data bekas. Pengumpulan data terutama dilakukan melalui teknik penelitian kepustakaan (library research dan online research), dengan menghitung data sekunder yang diperlukan, meliputi bahan hukum primer, sekunder dan tersier, kemudian melakukan penelusuran historis diantara bahan hukum tersebut dan sinkronisasi. yang digunakan antara lain peraturan perundangundangan khususnya yang berkaitan dengan perumusan peraturan perundang-undangan dan peranan hukum dalam pembangunan ekonomi. Bahan hukum sekunder yang akan digunakan antara lain: karya ilmiah, hasil penelitian dan dokumen-dokumen yang berkaitan dengan intisari penelitian. Bahan hukum tingkat ketiga, yaitu bahan yang mendukung informasi bahan hukum tingkat pertama dan kedua.

\footnotetext{
${ }^{2}$ Sabirin, "Perdagangan Perempuan Dengan Dalih Perkawinan Unpad, Sumedang 2017.
} 


\section{HASIL DAN PEMBAHASAN}

\section{A. Terjadinya Kasus Tindak Pidana Perdagangan Perempuan dan Anak}

Kasus perdagangan perempuan dan anak human trafficking di Indonesia diperkirakan sangat tinggi, ibarat fenomena gunung es yang hanya terdeteksi sedikit di permukaan. Kasus human trafficking ini ibarat fenomena gunung es dimana dari kasuskasus yang muncul ke permukaan, diperkirakan masih banyak lagi kasus-kasus yang tidak terungkap. Kasus perdagangan manusia, umumnya menimpa kelompok anak dan remaja di bawah umur 18 tahun. Modusnya, mereka direkrut dengan janji bekerja, tetapi kemudian diperkerjaan sebagai pekerja seks komersial. Celakanya lagi, sebagian dari korban perdagangan manusia ini diketahui terjangkit penyakit HIV/Aids. Di lapangan, mereka yang terkena penyakit ini mendapat perlakuan buruk saat kembali ke kampung halamannya ${ }^{3}$. Wakil Ketua LPSK Antonius PS Wibowo menerangkan faktor ekonomi paling dominan menjadi penyebab seseorang menjadi korban tindak pidana perdagangan orang (TPPO). Faktor itu tidak terlepas dari faktor pendidikan putus sekolah yang menempatkan korban dalam lingkaran perdagangan manusia.

Para pelaku memanfaatkan faktor-faktor tersebut dengan berbagai cara, diantaranya seperti menjanjikan penghasilan yang besar, memberikan pinjaman kepada keluarganya penjeratan utang, menjanjikan pekerjaan yang layak, dan beberapa cara lainnya seperti perkawinan. Tenaga Ahli LPSK Rully Novian menyampaikan dari pengalaman LPSK dalam menangani saksi dan korban TPPO, ada beberapa rekomendasi."Antara lain pemerintah harus memberikan perhatian khusus kepada wilayah-wilayah asal korban TPPO dengan cara meningkatkan kesempatan kerja dan mengentaskan kemiskinan di daerah tersebut. Penegak hukum juga harus meningkatkan profesionalitas dalam melakukan penindakan agar pelaku utama dalam sindikat perdagangan orang dapat dipidanakan. Rekomendasi lainnya, para pelaku sebaiknya tidak diberikan hak-hak narapidana remisi, pembebasan bersyarat apabila mereka tidak membayarkan restitusi kepada korban ${ }^{4}$.

3 KEMENPPPA, Kementerian Pemberdayaan Perempuan dan Perlindungan Anak Republik Indonesia Perdagangan Perempuan dan Anak Bagai Fenomena Gunung Es, https://kemenpppa.go.id/index.php/page/ $\mathrm{read} / 30 / 549 /$ perdagangan-perempuan-dan-anak-bagai-fenomena-gunung-es, diakses pada 20 Agustus 2021.

4 Rr Laeny Sulistyawati, "Christiyaningsih, Factor Ekonomi Mendominasi Penyebab Perdagangan Orang" Repiblika.co.id, 2019, diakses pada 2 September 2021. 


\section{JURTE-ISSN: 2723-0147}

Perdagangan orang dapat diartikan segala bentuk kegiatan yang diarahkan pada upaya bujukan, pengiriman, pengalihan, atau pemberangkatan dan penyerah terimaan seseorang yang tidak sesuai dengan hati nurani dengan menggunakan kekerasan, pemaksaan menakut-nakuti, penculikan atau penipuan dalam berbagai bentuk dari penyalahgunaan kekuasaan terhadap yang lemah (rentan) sehingga menimbulkan ketakutan, paksaan, penipuan termasuk yang timbul dari ikatan perutangan dengan pembayaran tenaga dan atau ikatan perjanjian kerja paksa dan penghambatan, dengan maksud untuk mendapat bayaran, keuntungan, atau penguasaan atas hak kebebasan seseorang dengan tujuan mengekspolitasi hak-hak seseorang. Termasuk dalam pengertian perdagangan orang dan anak adalah tindakan eksploitasi pelacuran, atau eksploitasi dalam bentuk sekecil apapun seperti pelacuran, pemaksaan, hubungan seksual, pekerja paksa, perbudakan, penghambatan bahkan sampai penjualan bagian dari organ tubuh tertentu.

Tak dapat dipungkiri bahwa hukum internasional memainkan peranan yang sangat penting dalam kehidupan masyarakat internasional. Melalui hukum internasional negaranegara merumuskan prinsip-prinsip hubungan dan kerja sama di berbagai bidang kegiatan untuk mencapai tujuan bersama. Melalui ketentuan-ketentuan hukum internasional, negaranegara mencegah terjadinya sengketa dan menyelesaikan sengketa yang telah terjadi. Melalui hukum internasional, yang dirumuskan dalam berbagai bentuk perjanjian internasional, negara-negara menggabungkan upaya mereka untuk menangani isu-isu global mulai dari masalah-masalah kemiskinan, sosial ekonomi, keamanan, perlucutan senjata, HAM, lingkungan hidup sampai pada terorisme. ${ }^{5}$ Tanpa adanya ketentuanketentuan hukum internasional, dunia tidak mungkin mencapai kemajuan dan kehidupan yang harmonis. Tanpa adanya kehidupan yang harmonis antar negara tidak mungkin pula dicapai perdamaian dan keamanan yang sangat dibutuhkan bagi kesejahteraan umat manusia. Pengertian perdagangan perempuan yang paling sering digunakan adalah pengertian yang diberikan oleh Protokol Perdagangan Manusia. Perdagangan manusia adalah perekrutan, pengangkutan, pemindahtanganan, penampungan atau penerimaan orang.

UNICEF mendefinisikan perdagangan anak adalah tindakan perekrutan, transportasi, transfer, menyembunyikan atau menemui seorang anak dengan tujuan untuk

\footnotetext{
5 Abang Ishar, "Perdagangan Perempuan", Jurnal Final Rahema, Vol. 2, No.1, Juni 2017. Sabirin, Perdagangan Perempuan Dengan Dalih Perkawinan.
} 
eksploitasi baik di dalam maupun di luar suatu negara. Pada Pasal 3 huruf (a) Konvensi ILO No. 182 menyebutkan bahwa bentuk terburuk pekerjaan untuk anak didefinisikan sebagai segala bentuk perbudakan atau praktek sejenis perbudakan, seperti penjualan dan perdagangan anak, kerja izin dan perhambaan, wajib kerja atau kerja paksa, termasuk pengerahan anak secara wajib atau paksa untuk dimanfaatkan dalam konflik bersenjata. Selanjutnya Konvensi ILO No. 182 melarang adanya perbudakan, penjualan dan perdagangan anak-anak, kerja paksa dan kerja ijon (termasuk pengerahan anak-anak dalam konflik bersenjata), serta penyediaan, atau pemanfaatan anak-anak untuk pelacuran, pornografi, obat-obatan terlarang, dan pekerjaan, yang karena hakikatnya atau lingkungan tempat pekerjaan itu dilaksanakan, mungkin membahayakan kesehatan, keselamatan atau moral anak-anak. Pasal 2 Optional Protocol to the CRC on the Sale of Children, Child Prostitution and Child Pornography, 2000 selanjutnya disebut Protokol Opsional Konvensi Hak Anak (KHA) Tahun 2000, mengartikan penjualan anak adalah segala tindakan atau transaksi di mana seorang anak ditransfer oleh segala orang atau kelompok orang ke orang lain untuk mendapatkan imbalan atau pertimbangan lainnya. Dalam hubungannya dengan Pasal 3 Protokol Palermo, dan Konvensi ILO No. 182, hal ini berarti bahwa perekrutan, pengangkutan, pemindahan, penampungan atau menerima seorang anak di bawah usia 18 tahun untuk tujuan pelacuran dan pornografi harus dianggap sebagai perdagangan manusia ${ }^{6}$.

\section{B. Faktor Penyebab Adanya Perdangan Perempuan dan Anak}

Faktor utama yang menyebabkan terjadinya perdagangon perempuon dan anak, ada;ah karena: kemiskinan, pendidikan rendah, kawin usia dini; dan ketidaktaatan terhadap ajaran agama. Faktor-foktor penyebab tersebut merupakan akar permasalahan terjadinya kasus tindak Perdagangan Perempuan dan Anak (Abu Hanifah) pidana perdagangan perempuan dan anak. Untuk mencegah meluas dan mening kotnya kasus perdagangan perempuan dan anak, maka akar permasalahannya perlu dihilangkan dan alternatif untuk menghilangkannya melalui pemberdayaan sosial keluarga. Keempat faktor penyebab tersebut akan diuraikan satu persatu sebagai berikut:

\footnotetext{
${ }^{6}$ Trizata Ayu Pramesti. (2019). “Jerat Pidana Bagi Pelaku Perjualan Anak” diakses pada 15 Agustus 2021
} 
a. Kemiskinan

Tingkat ekonomi yang rendah seringkali menjadi sumber munculnya sejumlah masalah sosial, antora lain semakin banyak jumlah pengemis dan anak-anak terlantar. Tidak jarang kemiskinan menjadi pangkal bagi munculnya disharmoni keluarga, termosuk di dalamnya muncul praktik perdagongan anak perempuan untuk tujuan pelacuran ${ }^{7}$ dianggap sebagai faktor penting yang menjadi penyebab terjadinya perdagangan perempuan don anak. Penduduk miskin tidak hanya memiliki keterbatasan pilihan-pilihan untuk mencari sumber penghidupan, tetapi mereka juga hanya memiliki sebagian kekuasaan sosial untuk mengontrol kondisi lingkungan yang menekan dirinya. Keinginan untuk memperbaiki kondisi yang demikian seringkali membuat banyak perempuan memilih untuk melakukan migrasi. Karena ketidaktahuan informasi tentang daerah tujuan dan keinginan untuk memperbaiki nasib, mereka justru menghadapi risiko untuk diperdagangkan. Penelitian yang berjudul "utang selilit pinggang-Sistem ijon dalam pedagangan anak perempuan" yang dilakukan oleh Johanna Debora Imelda dkk pada tahun 2004 di Jakarta Utara, dapat dikemukakan bahwa responden sebanyak 50 orang anak perempuan yang berumur 13 s.d. 18 tahun sebagian besar atau 76 persen berasal dari Indramayu. Pekerjaan orangtua mereka sebagian besar adalah buruh tani (53.7\%) dengan jumlah tanggungan rata-rata 4-6 orang. Dengan demikian dapat disimpulkan bahwa mereka berasal dari keluarga miskin. Untuk menghilangkan faktor penyebab sebagai akar permasalahan yang memicu terjadinya tindak pidana perdagangan perempuan dan anak, maka terhadap keluarga yang demikian perlu ditingkatkan kondisi ekonomi mereka dengan memberi bantuan serta bimbingan peningkatan usaha ekonomi produktif.

\section{b. Prendidikan Rendah}

Tingkat pendidikan yang rendah, juga menjadi salah satu faktor yang dapat menjerumuskan anak perempuan ke dalam praktik perdagangan manusia. Ini dapat dipa hami mengingat dalam komunitas yang mengedepankan nilai -nilai patriarki, anak perempuan ditempatkan sebagai warga kelas dua, dan anak laki-laki yang diutamakan untuk mendapat pendidikan yang lebih tinggi ${ }^{8}$. Dengan pendidikan yang rendah mudah sekali ditipu oleh para calon yang menjanjikan pekerjaan yang "baik" dengan gaji yang

\footnotetext{
${ }^{7}$ Firdaus, Muhammad dkk. 2004. Perkoperasian, Sejarah, Teori dan Prakt. Bogor: Penerbit Ghalia Indonesia, hlm. 12.

8 Ibid, hlm. 13.
} 


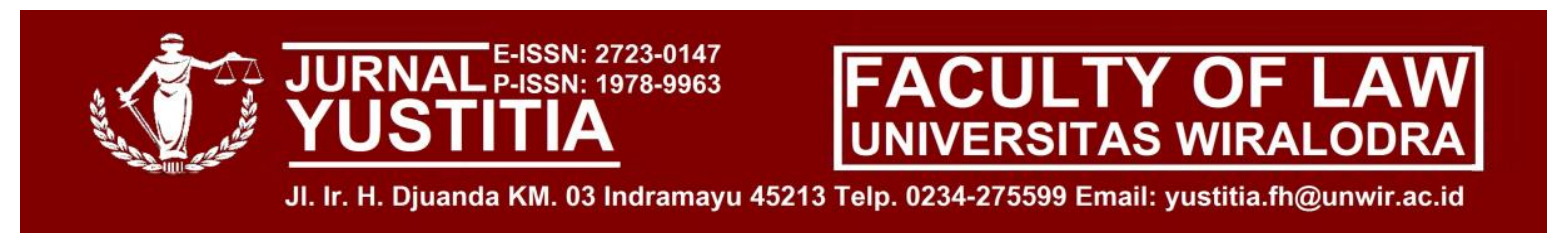

besar, namun sesungguhnya suatu trik tipuan untuk dipekerjakan di tempat atau lokasi pelacuran. Conteh kasus tindak pidana perdagangan perempuan karena tertipu, dan akhirnya di jerumuskan ke dunia pelacuran di Malaysia antara lain: pada tanggal 25 Juni tahun 2004, dua dari tiga perempuan yang berasal dari Kalimantan barat di pulangkan dari Malaysia, mengaku menjadi korban perdagangan manusia. Mereka menjanjikan akan dipekerjakan sebagai buruh pabrik di Malaysia, ternyata dijerumuskan m enjadi pekerja seks komersial di Kuala Lumpur. Untuk mengatasi hal tersebut, melalui pemberdayaan sosial keluarga perlu diberi wewenang terhadap keluarga yang menjadi sasaran pem berdayoan mengenai hak dan kewaj iban anggota keluarga dan tidak membedakan jenis kelamin dalam mengikuti pendidikan. Disamping itu, perlu juga diberi berbagai wawasan mengenai trik-trik penipuan yang sering digunakan oleh para colon tenaga kerja di dunia pelacuran.

\section{c. Perkawinan Usia Dini}

Batas minimal usia nikah dalam Undang-Undang Perkawinan sebagaimana dinyatakon dalam Undang-undang Perkawinan adalah 19 tahun bagi laki-laki dan perempuan ${ }^{9}$. Selanjutnya Mulia mengutip hasil penelitian yang dilaksanakan oleh UIN Jakarta (2000) mengungkapkan temuan rata-rata usia ideal perempuan untuk menikah berkisar 19.9 tahun dan laki-laki 23,4 tahun. Kematangan usia tersebut idealnya berupa akumulasi kesiapan fisik, ekonomi, sosial, mental dan kejiwaan agama dan budaya. Perkawinan pada usia dini bagi perempuan menimbulkan berbagai resiko, baik bersifat biologis seperti kerusakan organ reproduksi, kehamilan muda, dan resiko psikologis berupa ketidakmampuan mengemban fungsi-fungsi reproduksi dengan baik. Kehidupan keluarga menuntut adanya peran dan tanggungjawab yang besar bagi laki-laki dan perempuan. Hasil penelitian yang dilakukan oleh Johanna Debora Imelda dkk di Jakarta Utara, menunjukkan bahwa responden sebanyak 50 oraang yang berusia $13 \mathrm{~s} / \mathrm{d} 18$ tahun ternyata 12 persen berstatus kawin, sebesar 22 persen berstatus janda dan sebanyak 66 persen belum menikah. lni berarti sebanyak 34 persen sistem ijon dalam perdagangan anak perempuan telah melakukan kawin usia dini. Untuk mengatasi hal tersebut, melalui pemberdayaan sosial

\footnotetext{
9 Undang-undang Nomor 16 Tahun 2019 Tentang Perubahan Atas Undang-Undang Nomor 1 Tahun 1974 Tenatang Perkawinan
} 


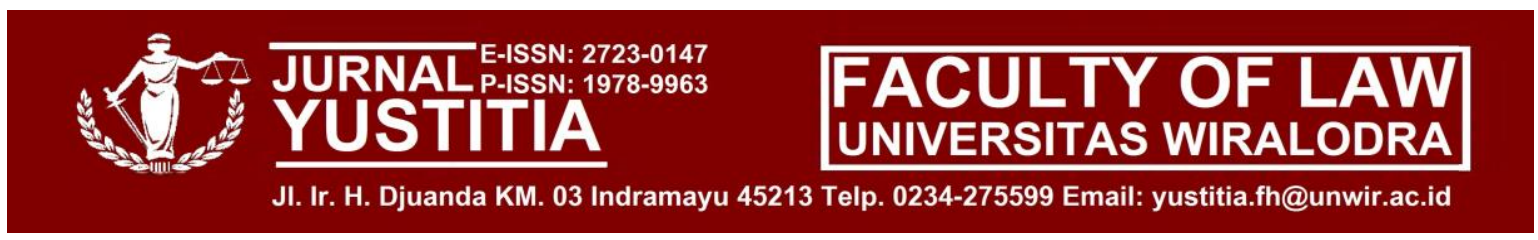

keluarga perlu disosialisosikan Undang-Undang Perkawinan agar mereka mengetahui resiko yang akan dihadapi apabila mereka melaksanakan pernikahan usia dini.

\section{d. Ketidaktaatan Menurut Agama}

Faktor yang juga penting untuk menjelaskan persoalan trafficking secara umum adalah adanya keterlibatan orangtua sebagai salah satu unsur pelaku trafficking tersebut. Beberapa studi tentang perdagangan anak rnelaporkan bahwa cukup banyak kasus perdagangan anak melibatkan orangtua. "Respons LSM terhadap Perdagangan Anak di Surabaya", menegaskan bahwa fenomena kasus dua orangtua menjadi gerrno bagi anaknya ${ }^{10}$. Kasus trafficking di kota Bandung dan Jawa Barat secara umum yang melibatkan orangtua sebagai pelaku lebih banyak disebabkan kondisi ekonomi keluarga yang kurang ${ }^{11}$. Kemudian penelitian yang dilakukan ILO di Jakarta dan Jawa Timur tentang perdagangan anak untuk eksploitasi seksual menunjukkan jaringan perdagangan tersebut melibatkan berbagai pihak ${ }^{12}$. Pertama, dari orang-orang terdekat korban, seperti orangtua yang mempersiapkan anak-anaknya, baik secara sosial, psikologis, maupun spiritual, saudara atau tetangga yang biasanya berperan sebagai mata-mata untuk menyeleksi anak-anak yang depot direkrut. Kedua, calo yang berperan sebagai mediator dalam bisnis seksual. Ketiga, tokoh formal maupun informal yang memperlancar sistem kerja bisnis seksual tersebut. Keempat, adalah mucikari yang bertanggungjawab terhadap fasilitas yang memungkinkan terjadinya tranksaksi seksual antara korban dan pemakai ${ }^{13}$.

\section{PENUTUP}

\section{A. Simpulan}

1. Perdagangan perempuan dan anak cukup memprihatinkan. Faktor utama terjadinya tindak pidana perdagangan perempuan dan anak ini adalah kemiskinan, Pendidikan rendah, kawin diusia dini dan ketidaktaatan pada ajaran agama. Terobosan tersebut dapat dilihat dalam kesepakatan mengenai definisi kelompok terorganisasi (criminal group) dan ruang lingkup dari kejahatan transnasional. Luasnya cakupan

\footnotetext{
${ }^{10}$ Firdaus, M, Ekonometrika Suatu Pendekatan Kualitatif. Bumi Aksara: Jakarta, 2004, hlm. 18-19.

${ }^{11}$ Irwanto.dkk. 2001, Pengaruh Hormon IBA (Indole Butyric Acid) Terhadap Persen Jadi Stek Pucuk Meranti Putih (Shorea Montigena). Tugas akhir/skripsi Tidak Diterbitkan Jurusan Kehutanan Unversitas Pattimura Ambon.

${ }^{12}$ Imelda, R.H.N, Implementasi Balanced scorecard Pada Organisasi Publik. Jurnal Akuntansi Dan Keuangan 6 (2), 2004, hlm. 26.

${ }^{13}$ Jumal Pelitian dan Pengembangan Kesejahteraan Sosia, Vol 13, No. 02, 2008: 46-60
} 
kejahatan transnasional dengan dipeloporinya tiga protokol sebagai bagian dari Konvensi Palermo, yakni perdagangan orang, khususnya perempuan dan anakanak; penyelundupan migran; dan perdagangan gelap senjata api. Hal itu membuka pengertian bahwa Konvensi Palermo dapat dimanfaatkan untuk mencegah dan memberantas kejahatan transnasional lainnya.

2. Selama ini, pengaturan tentang perlindungan hukum terhadap Perempuan dan Anak Korban Kejahatan Perdagangan Manusia tersebar dalam beberapa peraturan perundang-undangan baik yang sifatnya umum maupun khusus, seperti: Kitab Undang-Undang Hukum Pidana, Undang-Undang No.21 Tahun 2007 tentang Pemberantasan Tindak Pidana Perdagangan Orang, Undang-Undang No.13 Tahun 2006 tentang Perlindungan Saksi dan Korban. Perlindungan hukum yang diberikan oleh KUHP baru secara abstrak dan belum diberikan secara langsung atau konkrit

\section{B. Saran}

Mengingat faktor utama penyebab terjadinya kasus tindak pidana perdagangan perempuan dan anak adalah kemiskinan, Pendidikan rendah, kawin diusia dini, ketidaktaatan pada ajaran agama dan tidak sedikit orang tua ikut terlibat dalam dalam kasus trafficking. Ini menunjukan lemahnya ketahanan sosial keluarga. Disarankan kepada unit terkait pemberdayaan peran keluarga dapat meningkatkan peran dan fungsi keluarga dengan memperhatikan kesimbangan bantuan yang bersifat ekonomis produktif dengan pelayanan sosial psikologis.

\section{DAFTAR PUSTAKA}

\section{A. Buku :}

Firdaus, Muhammad dkk. 2004. Perkoperasian, Sejarah, Teori dan Prakt. Bogor: Penerbit Ghalia Indonesia, hlm. 12

Imelda, R.H.N, Implementasi Balanced scorecard Pada Organisasi Publik. Jurnal Akuntansi Dan Keuangan 6 (2), 2004,

\section{B. Jurnal}

Abang Ishar, "Perdagangan Perempuan", Jurnal Final Rahema, Vol. 2, No.1, Juni 2017. Sabirin, "Perdagangan Perempuan Dengan Dalih Perkawinan 
Jumal Penelitian dan Pengembangan Kesejahteraan Sosia, Vol 13, No. 02, 2008: 46-60

\section{Undang-undang}

Undang-undang Dasar 1945

Undang-Undang Nomor 11 Tahun 2008 tentang Informasi dan Teknologi Elektronik

Undang-undang Nomor 16 Tahun 2019 Tentang Perubahan Atas Undang-Undang Nomor 1 Tahun 1974 Tenatang Perkawinan

\section{Sumber Lain}

Irwanto.dkk. 2001. Pengaruh Hormon IBA (Indole Butyric Acid) Terhadap Persen Jadi Stek Pucuk Meranti Putih (Shorea Montigena). Tugas akhir/skripsi Tidak Diterbitkan. Jurusan Kehutanan Unversitas Pattimura Ambon.

KEMENPPPA, Kementerian Pemberdayaan Perempuan dan Perlindungan Anak Republik Indonesia Perdagangan Perempuan dan Anak Bagai Fenomena Gunung Es, https://kemenpppa.go.id/index.php/page/read/30/549/perdagangan-perempuan-dan-anak-bagai-fenomena-gunung-es, diakses pada 20 Agustus 2021.

Rr Laeny Sulistyawati, “Christiyaningsih, Factor Ekonomi Mendominasi Penyebab Perdagangan Orang” Repiblika.co.id, 2019, diakses pada 2 September 2021. Sabirin, "Perdagangan Perempuan Dengan Dalih Perkawinan Unpad, Sumedang 2017. Trizata Ayu Pramesti. (2019). “Jerat Pidana Bagi Pelaku Perjualan Anak” Diakses pada tanggal 15 Agustus 2021 